
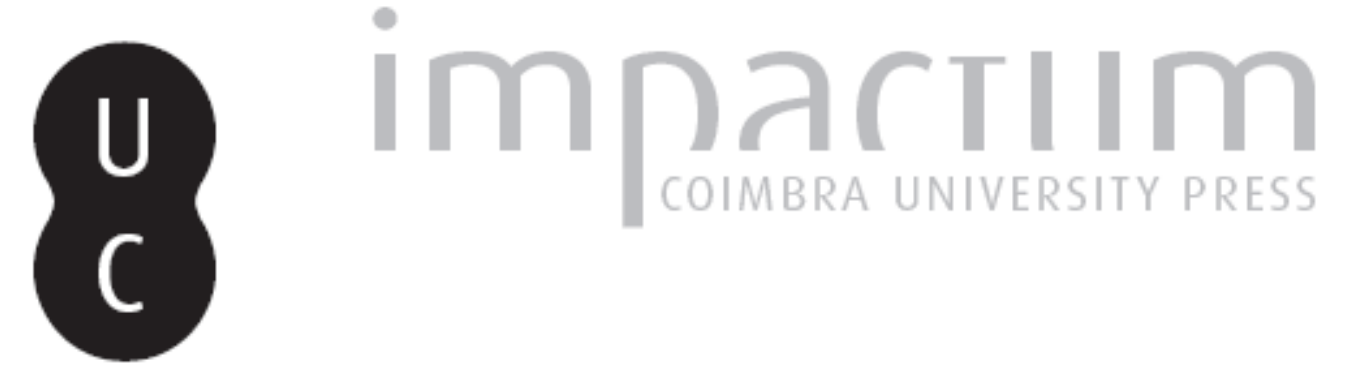

\title{
In search of modernist adaptability: a systematic approach for discussing the adaptive reuse potential of José Falcão School
}
Autor(es):
Coelho, Carolina

Publicado por: Editorial do Departamento de Arquitetura

URL persistente:

URI:http://hdl.handle.net/10316.2/45190

DOI:

DOI:https://doi.org/10.14195/1647-8681_9_12

Accessed : $\quad$ 26-Apr-2023 13:58:02

A navegação consulta e descarregamento dos títulos inseridos nas Bibliotecas Digitais UC Digitalis, UC Pombalina e UC Impactum, pressupõem a aceitação plena e sem reservas dos Termos e Condições de Uso destas Bibliotecas Digitais, disponíveis em https://digitalis.uc.pt/pt-pt/termos.

Conforme exposto nos referidos Termos e Condições de Uso, o descarregamento de títulos de acesso restrito requer uma licença válida de autorização devendo o utilizador aceder ao(s) documento(s) a partir de um endereço de IP da instituição detentora da supramencionada licença.

Ao utilizador é apenas permitido o descarregamento para uso pessoal, pelo que o emprego do(s) título(s) descarregado(s) para outro fim, designadamente comercial, carece de autorização do respetivo autor ou editor da obra.

Na medida em que todas as obras da UC Digitalis se encontram protegidas pelo Código do Direito de Autor e Direitos Conexos e demais legislação aplicável, toda a cópia, parcial ou total, deste documento, nos casos em que é legalmente admitida, deverá conter ou fazer-se acompanhar por este aviso.

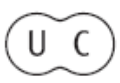



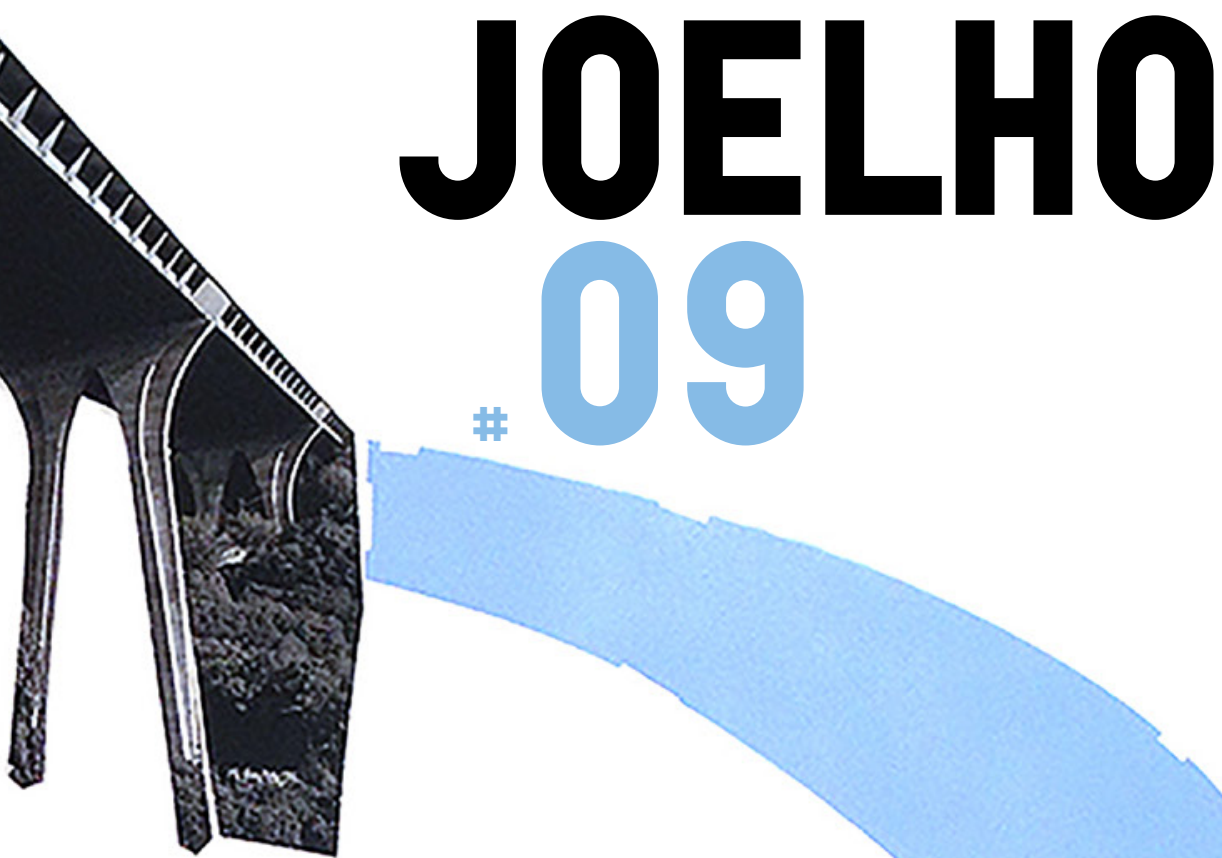

\section{REUSE OF MODERNIST BUILDINGS: PEDAGOGY AND PROFESSION}

Guest Editors:

Michel Melenhorst

Paulo Providência

Gonçalo Canto Moniz

ZUS: Elma van Boxel

and Kristian Koreman

Atelier do Corvo

Tilemachos Andrianopoulos

Albena Yaneva

Carlos Fortuna

Christian Gänshirt

Dieter Leyssen

Carolina Coelho

Anna Giovannelli

António Carvalho

Marta Peixoto

Els De Vos

and Eva Storgaard

Exhibition

$2^{\text {nd }}$ RMB Workshop, Coimbra

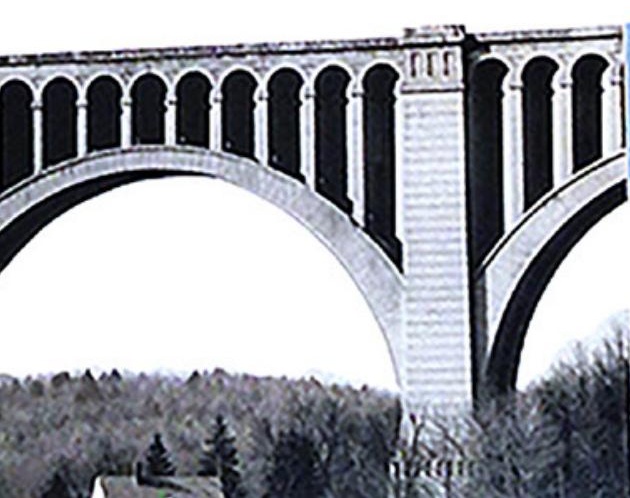




\section{Carolina Coelho}

In search of modernist adaptabijility

A systematic approach for

discussing the adaptive reuse

potential of José Falcão School
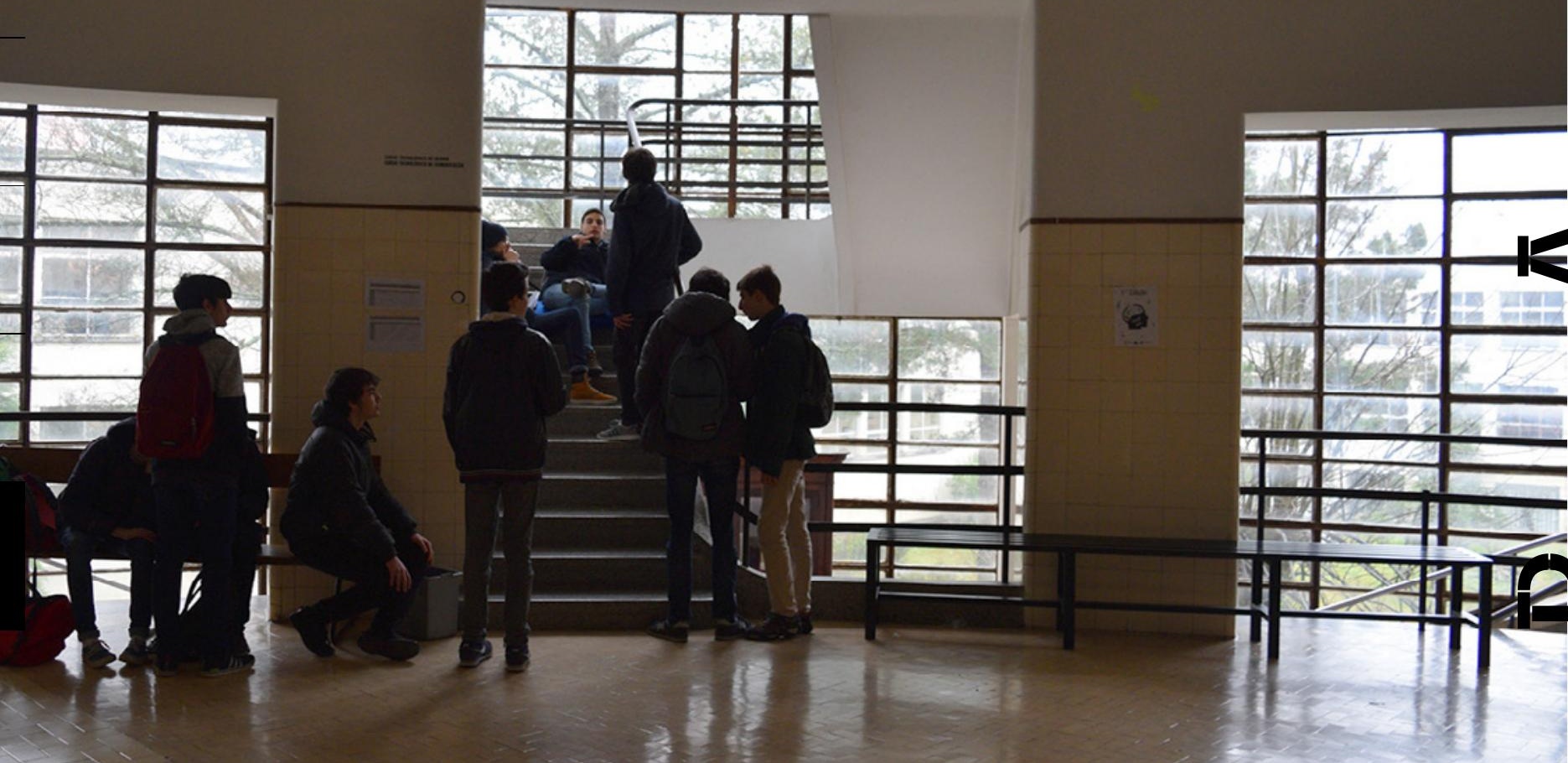


\section{Introduction:}

Contemporary learning practices and environments

Contemporary learning practices comprise the active creation of knowledge, surpassing passive lectures and reaching for the independent and critical thinker. This could be achieved either by construction, communication or evaluation moments, whose dynamics have to be spatially accommodated and fostered.

Some $2 \mathrm{O}^{\text {th }}$ century schools represent prominent moments of experimentation, whose focuses may vary, from the students' wellbeing and hygienist purposes of the Open-Air schools by modern architects like Duiker and Bijvoet (Amsterdam, 1927-30); to approaching the outdoors, as in Impington Village College by Walter Gropius and Maxwell Fry (Cambridgeshire, 1938-40); all in all reconsidering the students' immediate environment and the school's envelope in its regard between internal and external space.

Classroom configuration has also been subject of research, such as in Hans Scharoun's schools (Marl, 1960-71 and Darmstadt, 1951); or previously in Richard Neutra's Corona Avenue Elementary School (1934-35), or the Crow Island School by Eliel and Eero Saarinen with Perkins, Wheeler and Will (Winnetka, 1939-40).

Furthermore, the need for space growth and curricular change guided significant school building developments exemplified by the Hertfordshire post-war experience. Entitled as "a very great achievement" by Llewelyn-Davies and Weeks (1952, p. 368), it already fostered the possibilities of change in the school space.

Still, one of the most prominent spatial realisations of the contemporary schools is the acknowledgment of active learning environments, potentially decentralised from the educator or, primarily, from the traditional classroom. These can act as spaces where knowledge creation occurs amongst peers in informal moments with substantial learning potential. Recalling Herman Hertzberger: "learning has to be more than just absorbing basic knowledge" (Hertzberger, 2008, p. 8), recognising school in a more holistic manner and acknowledging its diverse spaces as a means to knowledge acquisition.

Even though these projects are not immediately associated with the concept of adaptability per se, these act as moments of research of alternative educational environments in regard to the school's multiple layers of analysis (Brand, 1994) and to its different scales of approaching the individual: either by its envelope, thresholds, partitioning, single classrooms or collective areas. This questioning of the learning spaces went along with the development of the learning practices, which cyclically implied the reconsideration of the spatial features to allocate them, acknowledging the concepts of "built pedagogies" (Monahan, 2002) and "educational tool" (Heitor, 2005) that bond school and learning.

Ultimately, and recognising both the spatial and pedagogical changes, adaptability is paramount to provide the schools with the
Frontispiece Socialisation and communication in the school's informal spaces (Images credits: author's archive) 
ability to cope with its practices, faculty and students' profile in the future. It is here assumed as "the ability of the built form to maintain compatibility between activities and spaces, as those vary" (Krüger, 1981, p. 1169), enabling the school to continue to allocate the broad range of contemporary learning activities within its preceding physical structure.

Already in the OECD's 1976 publication Providing for future change: Adaptability and flexibility in school building, it is pinpointed the advantages brought by adaptability, associated with the possible future changes on the learning practices and on the size of the learning spaces according to the demographics of the school community, and also the search for "the best match between environment and education" according to the design choices possible for architects to make early on (OECD, 1976, p. 9). There, the relevance of adaptability for schools is clear and understood as a quality factor, associated with change to which the schools would have to comply:

"[...] the educational requirements which school buildings have to meet evolve rapidly and unless the buildings can be made to accommodate future change, they are liable to early and costly obsolescence." (OECD, 1976, p. 5)

Specifically, the approach to adaptive reuse has also been taken on by several authors in recent approaches like Kincaid's (2003) book Adapting buildings for changing uses: Guidelines for change of use refurbishment, where adaptive reuse is defined as: "a complex process which requires that the participants in the process have a clear understanding of how to determine what future uses will be most appropriate for a particular building in a particular location and for a given period in time." (Kincaid, 2003, p. 10). This is linked with changing needs and also to the building's feasibility to hold other uses different from the initially conceived ones.

Recent publications and conferences concerning this subject matter have also been prolific on this matter. Docomomo has played a very significant role on this subject matter: the $14^{\text {th }}$ Docomomo International Conference (Docomomo, 2016) held in Lisbon was centred around Adaptive reuse: The modern movement towards the future, the 2015 Docomomo Journal 52 was called 'Reuse, Renovation and Restoration' (Docomomo, 2015) and Docomomo Ibérico has also specifically approached modern movement architecture and education as proven by the proceedings from the $8^{\text {th }}$ Iberian Docomomo Congress from 2013 (Docomomo Ibérico, 2015; Moniz, 2015.) All these have gathered a wide research community around this issue and consequently hold different perspectives and contributions towards knowledge advancement.

As the case study, this paper will focus on José Falcão Secondary School, in Coimbra, from 1930-1936, by Carlos Ramos, Jorge Segurado and Adelino Nunes, from the "Santa Cruz" design proposal (Moniz, 
2003; Moniz, 2007, pp. 170-178). In spite of subsequent alterations from the original design, it is an acknowledged national built heritage and holds undisputable spatial quality and urban representativeness within the city of Coimbra (Fig. 1).

Nevertheless, its physical obsolescence is evident, and despite the recent Secondary School Modernisation Programme extensively set out in Portugal, it has not been rehabilitated. Hence, the latest news on the media related to the struggle for urgent rehabilitation of the school.

On this regard and according to this prior introduction, three questions can be placed:

- How can a modernist building accommodate the current learning practices, as wide as these can be?

- What are the school's active learning environments?

- What is the adaptability potential of a modernist learning space towards informality and socialisation as a means for learning?

Thus, this paper aims at analysing the collective spaces used for the students' informal activities and to critically reflect upon their potential as active learning environments according to their adaptability condition (Fawcett, 1978; Coelho, 2017) by identifying criteria for assessing contemporary adaptable school spaces. Hence, adaptability is particularly relevant for this school, which continues to be working and that has to allocate the current academic and non-academic activities perceived as part of its evolving pedagogical curriculum (Fig. 2).
Fig. 1 José Falcão Secondary School.

Drawing of the façade with the lettering (left); the school in 2018 (right) (Drawing credits: the school archive; Photo credits: author's archive)
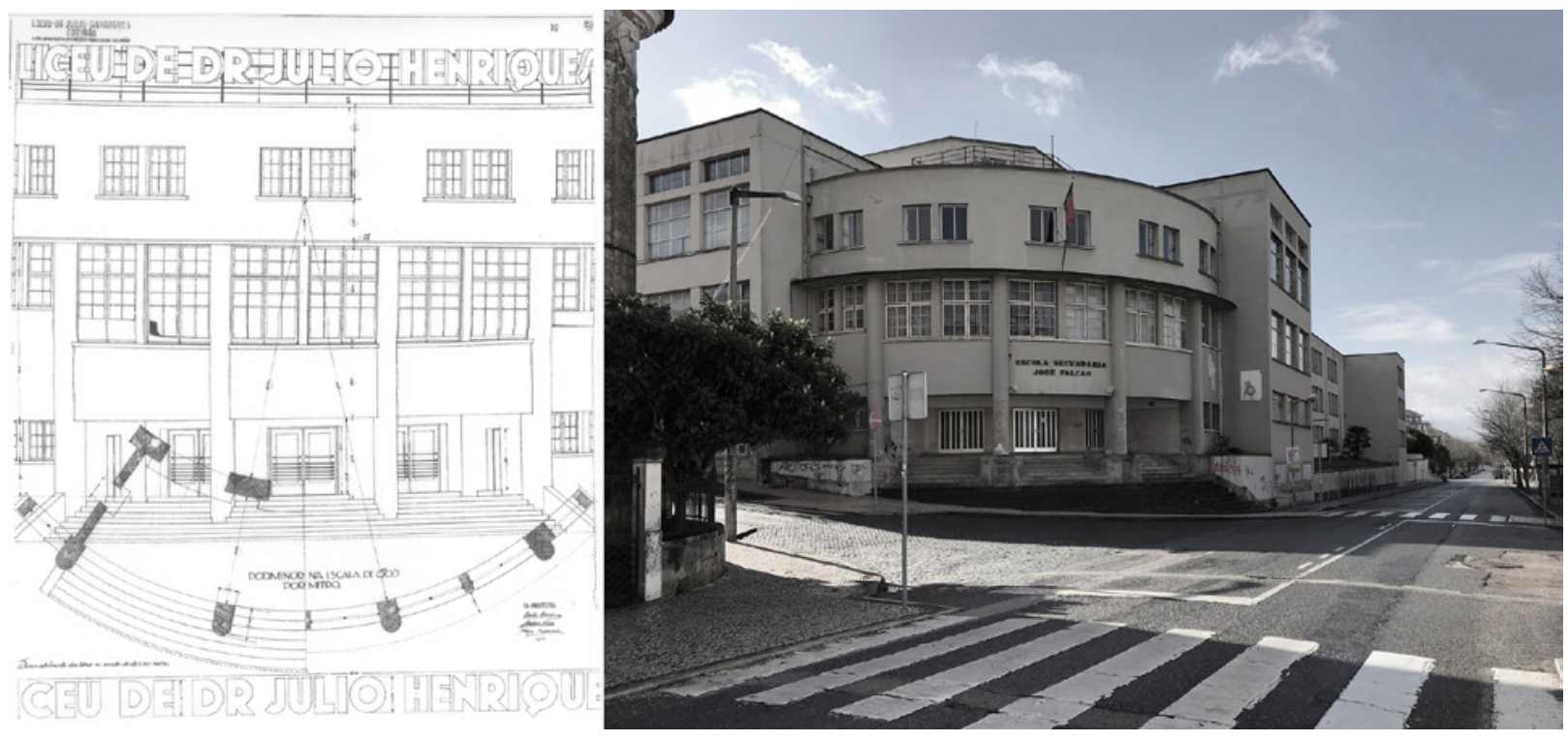

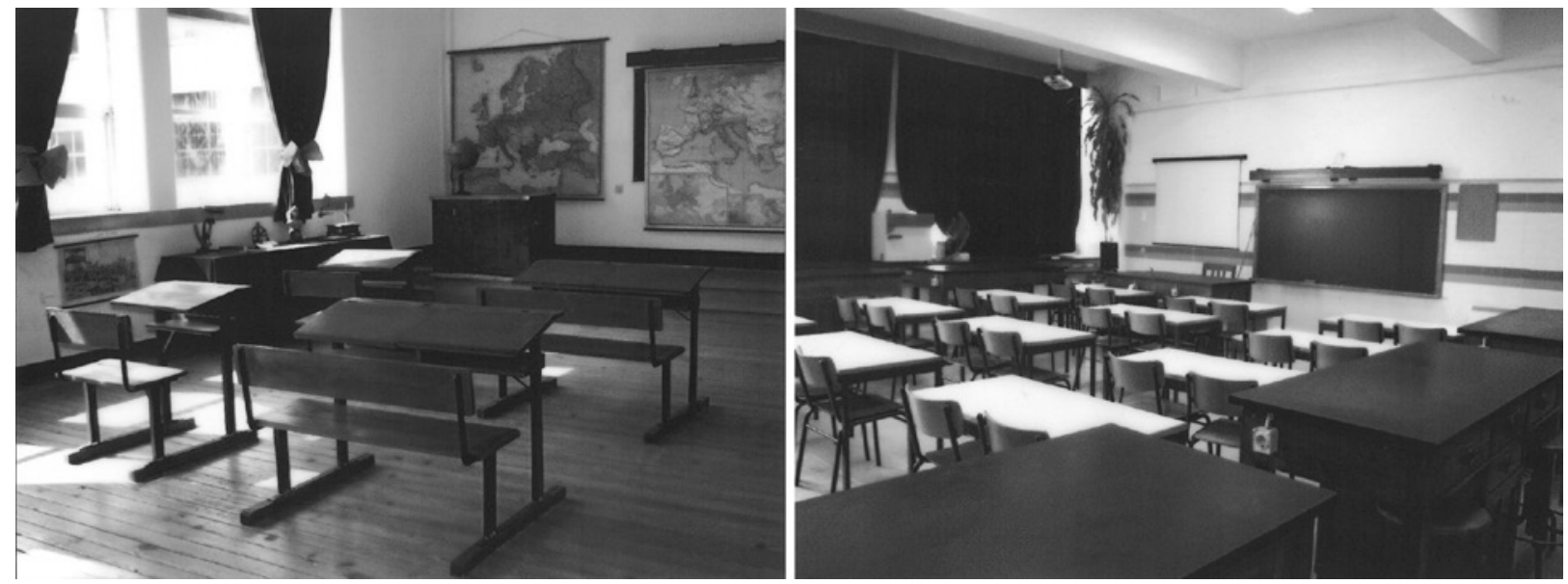

Fig. 2 José Falcão School's classrooms (Images credits: the school archive)

Fig. 3 Schematic synthesis of the methodology (Image credits: author's archive)
SCHEMATIC SYNTHESIS OF THE METHODOLOGY

I. DESCRIPTION OF THE SCHOOL SPACE

I.I DEFINITION OF THE SPATIAL SAMPLE functional analysis

II. DESCRIPTION OF ACTIVITY-SPACE ALLOCATIONS

II.I FEASIBILITY MATRIX

systematic analysis

Learning activities to active learning environment

III. DESCRIPTION OF EVENTS AND EXPERIENCE

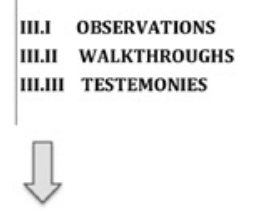

IV. ADAPTABILITY RETRIEVAL

Ultimately, it is intended to identify both the formal and informal spaces where adaptability can be higher and to provide a critical thinking on potential interventions to enhance them on this behalf, enabling the accommodation of current learning practices, as wide as these can be.

\section{A methodology for assessing the school's adaptability}

The methodological approach taken as the basis for this analysis is centred around three milestones:

- description of the spatial sample - consisting on the functional and morphological definition of the space; 
- description of activity-space allocations - understanding how and where are the learning activities accommodated in space;

- description of events and experience - defining what is the actual living experience and spatial appropriation in the school, by means of observations of spatial usage, walkthroughs and the recollection of testimonies from the whole school community.

These, ultimately, can be correlated towards the adaptability retrieval that enables an overview of the space overall on the activities each space holds, either formally defined or informally appropriated, and generally their potential for widening these allocations to other learning practices (Fig. 3).

\section{Description of the school space}

Initially, contemporary learning practices and spaces are addressed, realising the bond between the teaching and learning methods and the place to accommodate them, in the current manner perceived today, where socialisation and informality also imply knowledge communication and acquisition. Hence, the need to understand the whole school, for self-discovery, group work and formal and informal learning activities overall, both in its classrooms, as well as beyond them.

Naturally, these practices also involve the use of technological devices, both in and beyond class, spatially implying new spaces conceived for such purposes, or the inclusion of such devices in preexisting spaces.

For the purposes of assessing the school space, the drawings of the school have been accessed, in its original proposal from 1936 signed by the architects, from the school's archives (Fig. 4), and also the ones that depict its actual situation, after the successive alterations the school has undertaken, namely the addition of an upper floor in 1938 (Rodrigues, 2003). The latter are the ones used as the basis for this analysis, as they report the school's effective usage today, according to the present spatial layout of the school.

Despite the perceivable physical obsolescence of the school, it has tried to cope with some eminent needs. So, some arrangements have been made recently, in specific spaces, such as: the multimedia room, a study room for accompanied learning, a reading room for individual study, an exhibition room for both an internal and external community, and spaces for group gathering particularly on wider niches opened onto the circulations. It is also visible that spatial appropriation has also been accepted and enabled, namely by artistic expression on the interior walls, as a demonstration of the students' curriculum, but also changing the spaces' interior coatings.

Hillier and Hanson (1984) in The Social Logic of Space have stressed the bond between spatial properties and social relations, in which space "constitutes" and also "represents" "social knowables" (Hillier and Hanson, 1984, p. 48; Heitor, 2001, p. 23): 

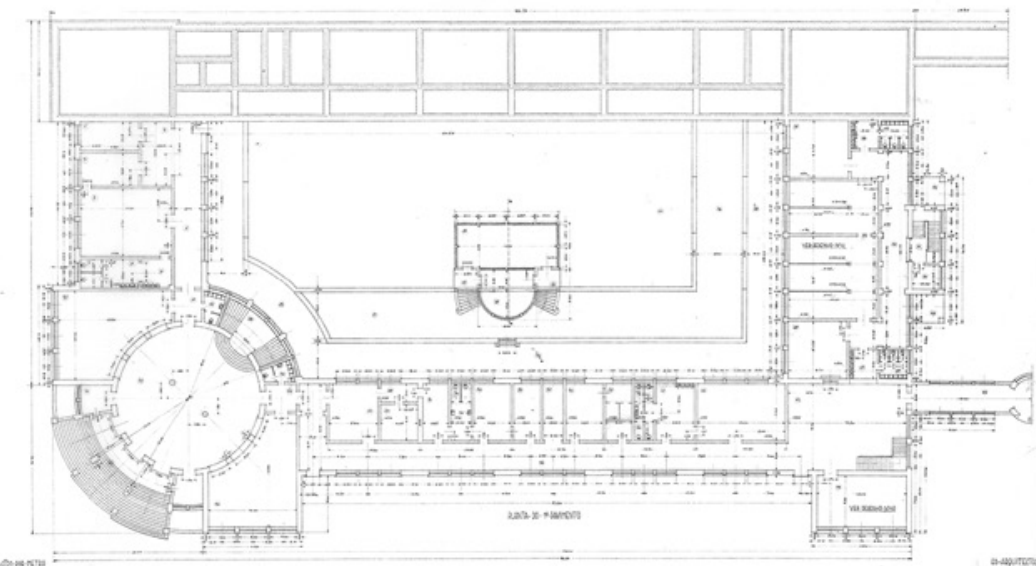

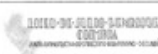

coston pacens

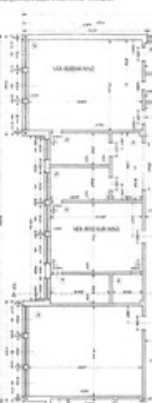

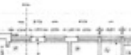

........

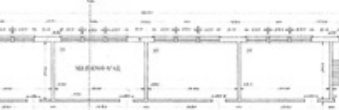

$\sqrt{3}$
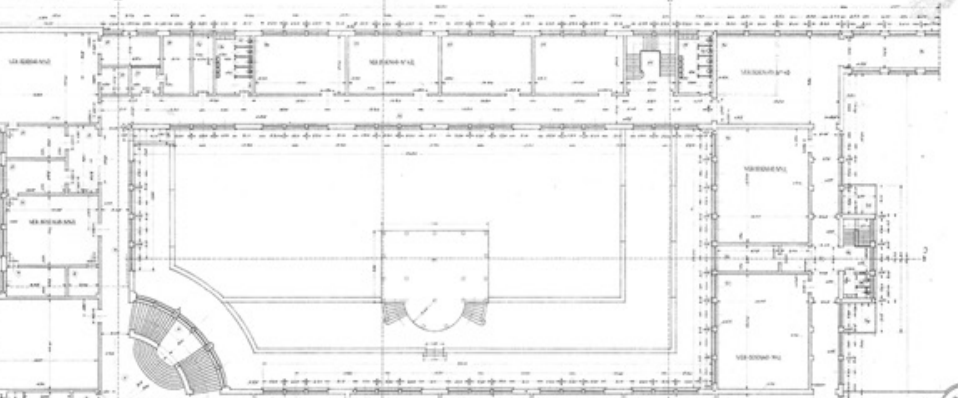

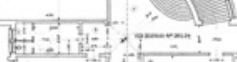

\&,

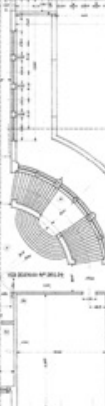

$\lim _{1+1}$
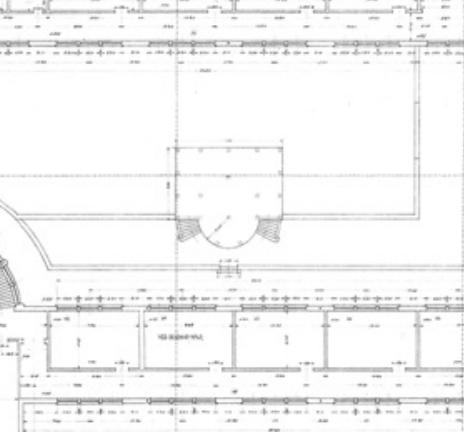

cou pasen:

$$
\text { - }
$$

:

+

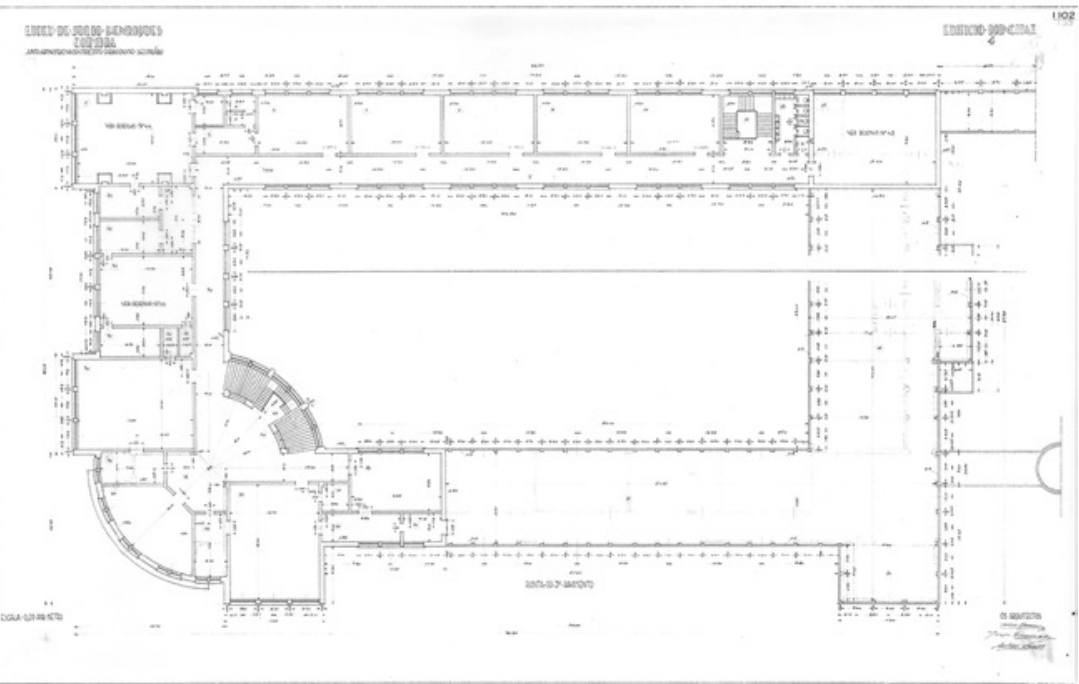


"By the assumption that what is to be sought is a relation between the 'social' subject (whether individual or group) and the 'spatial' object acting as distinct entities, space is desocialised at the same time as society is despatialised. This misrepresents the problem at a very deep level, since it makes unavailable the most fundamental fact of space: that through its ordering of space the man-made physical world is already a social behaviour. It constitutes (not merely represents) a form of order in itself: one which is created for social purposes, whether by design or accumulatively, and through which society is both constrained and recognisable. It must be the first task of theory to describe space as such a system." (Hillier and Hanson, 1984, p. 9)

So, the space syntax analysis, as defined by Hillier will be undertaken to further describe this spatial sample:

"Space syntax is a method we have developed at the Bartlett Unit for Architectural Studies to describe and analyse patterns of architectural space both at the building and urban level. The idea is that, with an objective and precise method of description, we can investigate how well environments work, rigorously relating social variables to architectural forms." (Hillier, Hanson, Peponis, Hudson and Burdett, 1983, p. 49)

For such purposes the school plans were edited in Autocad and imported to DepthmapX in order to proceed with the axial and visibility analysis. This provides information on the overall system of spatial relations between those spaces and the social dynamics these enable, either when standing, moving or visually perceiving space. When transferring this analysis onto the school space, this holds a paramount significance, because social experiences and interaction involve learning potential as a means of knowledge acquisition amongst peers.

Axial lines comprise not only the secluded spaces but a set of connected spaces that are recognised as a whole active learning environment, which brings added information to this analysis. Moreover, these also consider movement and standing as learning moments, not solely acknowledged in formally defined spaces or by academic activities, but also by informal, social and spontaneous experiences held throughout the whole school.

Even though a more thorough analysis is possible, this is focused on integration $\mathrm{HH}$ rn as the global measure that describes the overall system: "Clearly the more a space is integrated, the more it may be able to exploit the existing pattern of movement of people caused by the arrangement of space." (Hillier et al., 1983, p. 59). Furthermore, the axial line map also brings additional input regarding the most and the least integrated axial lines, informing where the student "communities
Fig. 4 Plans of the main building signed by the architects_ink on parchment paper (Images credits: the school archive) 
of educational and social practices" (Woolner, 2015, p. 10) ${ }^{1}$ displace the higher patterns of co-presence, encounters and movement conveyed by this school.

The axial line map (Fig. 5) reveals that the most integrated axial lines are located on the corridors and intersect several different programmatic areas of the school. These are identified in the warmest colours, whereas the axial lines with low integration are identified with the coolest colours, according to the traditional space syntax colour scheme.

As the school is scattered in a wide array of spaces displaced in several different hallways and floor plans, the integration might decrease. This is proven by the higher integration of the gym on the first floor, which displays numerous spaces around it, acting as a spatial, pedagogical and functional core of that part of the school. Opposite to this situation, the second floor plan, which does not have an horizontal circulation that connects these two parts of the school, implies a lower integration of each part, because of their lower centrality overall.

Even so, the openings on the main corridors, particularly near the library on the first floor and, even more clearly, upwards on the second floor near the amphitheatre, are highly integrated, coinciding with the location of the staircase that connects all three floor plans, functionally and collectively representing a meeting point for the student community for standing and also as a moving pathway.

On the contrary, spaces institutionally defined as spaces for the students to be, such as the cafeteria on the ground floor that is in a more segregated space, hold low axial integration. These correspond to a more time-consuming path to access them and a respective reduced frequency of stays there, hence, considered less engaging as opposed to spaces that are easier, quicker and more casually accessible for all.

The visibility analysis (Fig. 5) complements this information, identifying the spaces where the visual integration $\mathrm{HH}$ is higher and lower, assuming that high visibility enables more encounters and patterns of collective gathering, ultimately leading to interaction and learning, either amongst peers and also between students and educators. Similarly to the axial integration, the higher visual integration is again acknowledged on the main corridors.

The higher axial and visual integration values, identified in warmer colours in the axial lines and in the visual grid, are located where the two main buildings meet, which coincides with the students' entrance on the first floor; whereas the institutional entrance on the ground floor, which is the access point for the teachers, holds lower visual and axial integration towards the whole school. This segregation of the entrances between teachers and students potentially hinders interaction.

The study through isovists, as "the set of all points visible from a given vantage point in space and with respect to an environment." (Benedikt, 1979, p. 47), complements the previous analysis on spatial morphology for describing space, as: "Sets of isovists and isovist fields form an alternative description of environments." (p. 47). Thus, its study 

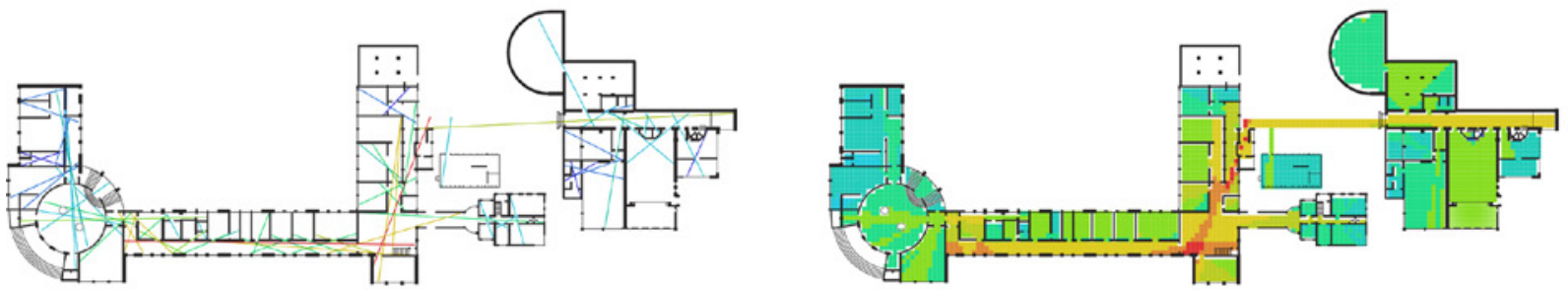

Ground floor
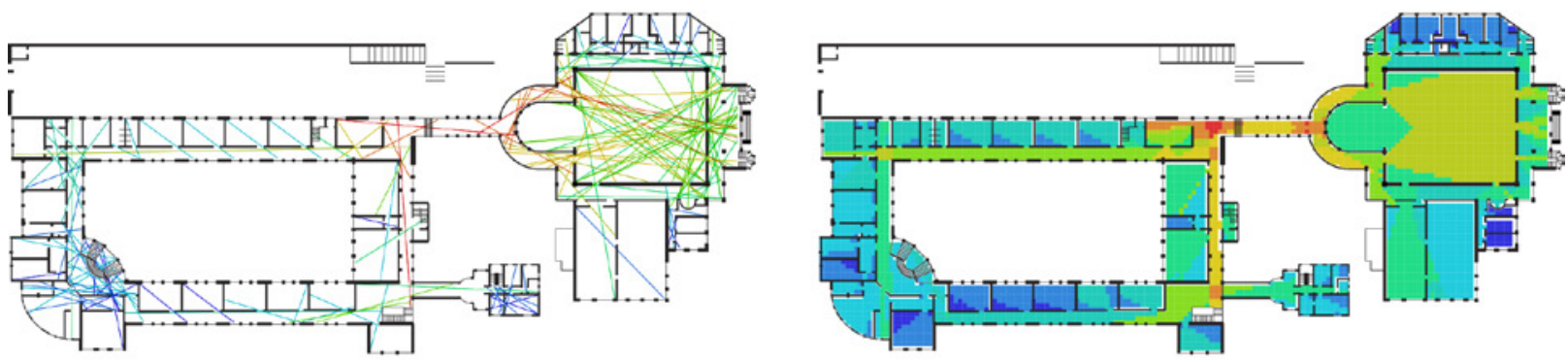

First floor
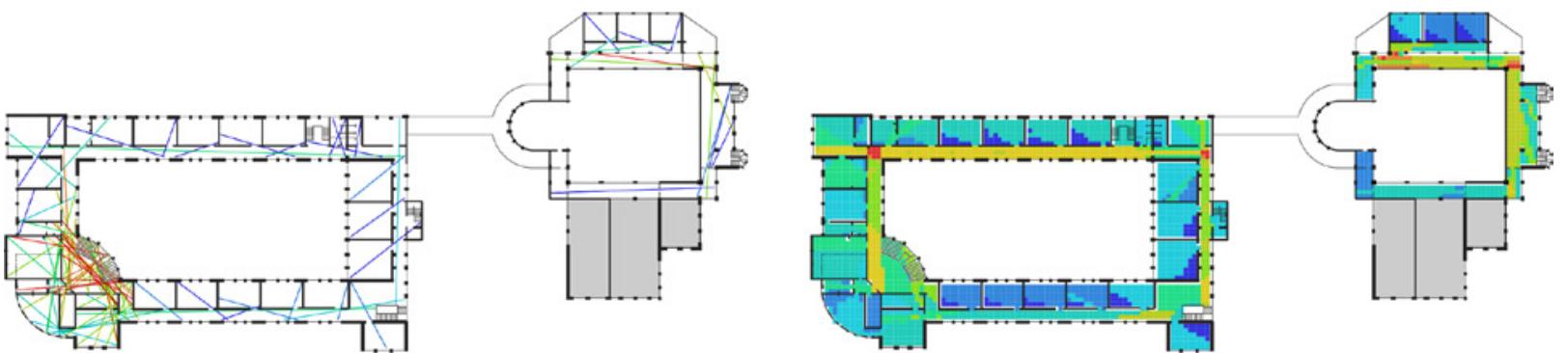

Second floor

also provides further input in regard to the visibility from several spots in space, where peer perception is higher, enabling also higher patterns of co-presence and encounters (Fig. 6). This occurs, particularly, on the students' entrance and on the four corners of the main building where the corridors meet. This can be articulated with the spaces where the students usually like to stand on their free time, which will be examined by milestone three of this methodology.

From the overall analysis, it is noteworthy the array of widespread spaces on the overall school and a lack of a more aggregating core of the school. Nevertheless, the morpho-syntactic analysis undertaken for the interior spaces of this school, proves that the main corridors are the spaces more prone to interaction, when moving from one space to another and by visually perceiving all the community.
Fig. 5 Axial Integration $\mathrm{HH}$ (left); Visual Integration HH (right) (Images credits: author's archive) 


\section{Description of the activity-space allocations}

After examining the spatial sample by means of a morphological approach, it is then possible to focus on its allocational potential towards contemporary learning activities, either group or/and individual, formal and/or informal.

Retrieving the initial questions, the school effectively holds active learning environments for the current learning activities, and these more recent rearrangements have aided on that behalf, namely with technological provision and the definition of social areas. However, these spaces are segregated between themselves by areas and nature of the events, and activities are site-specific and not widespread amongst the whole school. Generally, the exhibition room accommodates the displays from the school to the exterior community or vice-versa, the amphitheatre frequently holds the events for more than one class and the library shelters most of the remaining extra-curricular, formal and informal activities. Spaces such as the gym, the gym rooms, the canteen or the external spaces only occasionally accommodate some sporadic activities, as compared to the previous ones.

The systematisation of the activity-space allocations on a feasibility matrix aids to the visual perception of this situation. For such purposes, the learning activities can be divided in both: formal (academic and part of the schools' organisation and curriculum, e.g.: traditional lectures) and informal (social and often undertaken exclusively amongst the peers, e.g.: group gatherings); and each one could be acknowledged as: programmed (meaning of frequent usage or routinely occurrence, particularly within the school's weekly schedule, e.g.: formal study groups) and non-programmed (spontaneous or of occasional occurrence and not on a weekly based routine, e.g.: informal peer interaction) (Krüger, 1992).

The feasibility matrix is achieved by assigning the spaces to the effective learning activities they usually accommodate. This also confirms a segregation of spaces per type of activity and concludes on a low adaptability of the current spaces (Fig. 7). Even so, the most adaptable space is the library, which allocates the widest diversity of learning activities.

This can be overlapped to the concept of "looseness of fit" of activities to spaces that Fawcett parallels with the adaptability of that

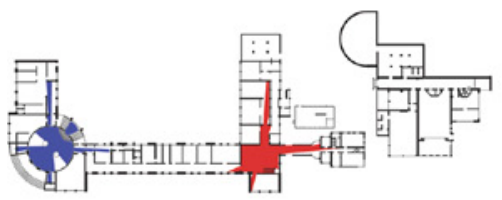

Ground floor

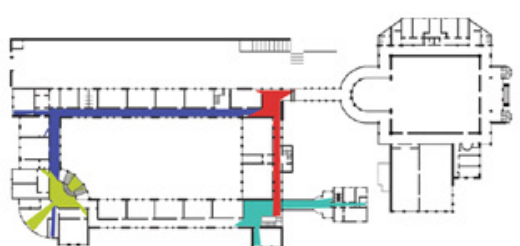

First floor

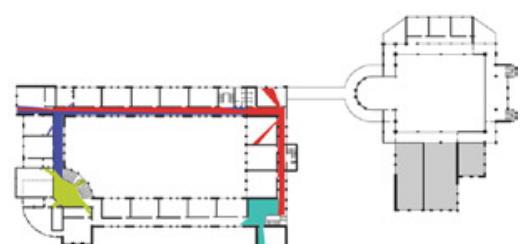

Second floor 


\begin{tabular}{ll} 
FORMAL & PROGRAMMED \\
\cline { 2 - 2 } INFORMAROGRAMMED & NONOGRAMMED \\
\cline { 2 - 2 } & SPONTANEOUS
\end{tabular}

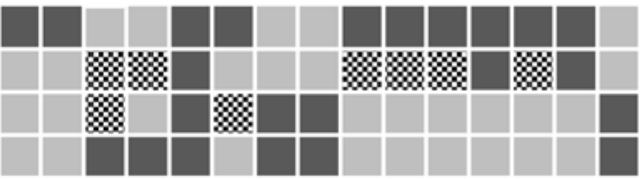

1 classrooms, 2 laboratories, 3 entrance hall, 4 circulation, 5 library, 6 amphitheatre, 7 cafeteria, 8 canteen, 9 gymnasium, 10 gym rooms, 11 auditorium, 12 exhibition room, 13 multimedia room, 14 study room, 15 students' lounge

\% proposed activity allocation per space

space, as such: "The pursuit of adaptability can be seen as maximising the looseness of the fit of the known activity schedule into the first-build physical schedule." (Fawcett, 1976b, p. 7). Hence, this considers that the higher the activity mix in each space, the more adaptable that space is to cater for different activities with a diverse array of spatial constraints. Ultimately, if the feasibility matrix is divided in learning activities of different nature: formal/informal, programmed/spontaneous; the "looseness of fit" implies that the most adaptable spaces can hold activities from a wide range of learning practices, which is enriching for the students.

This could be overcome if spatial allocations were widened to activities of more diverse nature, gathering formal/informal, and programmed/spontaneous experiences in the same or adjacent spaces. This is perceived in the feasibility matrix by means of the chequer pattern squares that enlarge the allocation potential of some of the most social and collective spaces and that, ultimately, propose a higher activity mix and higher entropy spaces (Fig. 7). For example, the entrance hall could hold a more representative role as an extracurricular learning space and occasional collective events could also be held in other spaces, such as the canteen for informal celebrations, or the auditorium that could be more extensively used for external and internal activities, as a way of disseminating the activities on the whole school space as a learning environment overall.

Hence, the results achieved on the library could be expanded towards other spaces, provided they can cope with them physically, and assuming that by management and spatial appropriation the school community uses them on other activities beyond the current ones.

\section{Description of the effective events and experience}

The last milestone of this research complements the previous findings on spatial fruition, for retrieving information on how the space is actually being appropriated and whether expected and effective use
Fig. 7 Description of activity-space allocations: Feasibility matrix _ actual and enlarged (Image credits: author's archive) 
overlap, enlarge or hinder the learning experience. This is undertaken by means of observations, walkthroughs and testimonies of the school's community.

Walkthroughs ${ }^{2}$ imply a visit to the school guided by its community, potentially students, teachers and staff, that define the pathways taken and show the spaces according to an initially defined goal, that in this case was the spaces that could be considered more adaptable.

A walkthrough has been made with the school director, who showed us the recent school's rearrangements towards current learning practices. Another one has been made with the school staff coordinator, who knows the school for longer and is in charge of all the spaces and equipment, who has also commented on the most representative spaces and their uses. The plans indicate the course of this longer walkthrough on the entire school (Fig. 8).

Besides observations, specific testimonies from the school community have also been gathered, enquiring on each person's spatial usage and the spaces considered to be active learning environments. These have been asked to the teachers and staff, and the results are displayed on the plans, according to the formal and informal spaces they have considered (Fig. 9).

Other testimonies have also been collected from students that provided their regard on their respective spatial fruition, which, again, has been displayed on the plans (Fig. 10). As perceived, there are some spaces that are unanimously considered by all, whereas on other spaces, the commentaries do not overlap: teachers and staff consider that informal activities occur in defined spaces of the school, while students perceive leisure and socialisation on the school overall, namely loosely on the circulations.

In fact, and besides the previously defined spaces for students to lay, informal activities and socialisation are perceived throughout all the school's circulations, namely on the benches placed on the corridors and on the niches and openings, as well as on exterior spaces, which are appropriated by students for their leisure and considered as meeting points.

Despite the tables and seating areas provided near the library, few students usually stand in those spaces. Students generally perceive the library as a more formal space, even though it is considered the most adaptable space that gathers both formal and informal activities. Formal events are usually placed on defined spaces such as the amphitheatre and the library. According to the students' testimonies, the auditorium is seldom used and the cafeteria and the canteen are not spaces where the students prefer to spend their time other than needed. Moreover, students appreciate standing in the corridors on the benches near the classes and on the circulations overall, namely on the niches and alcoves. Overall, separate areas for learning, for entering the school and for formal and informal activities, enhance spatial segregation and low adaptability. 


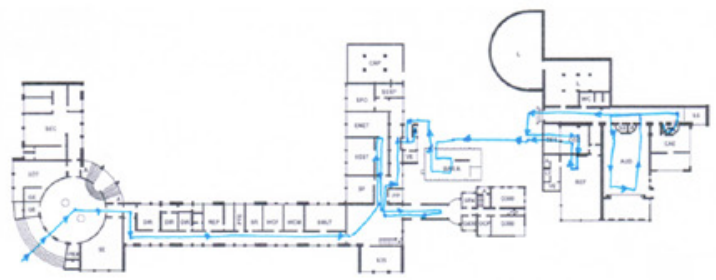

Ground floor

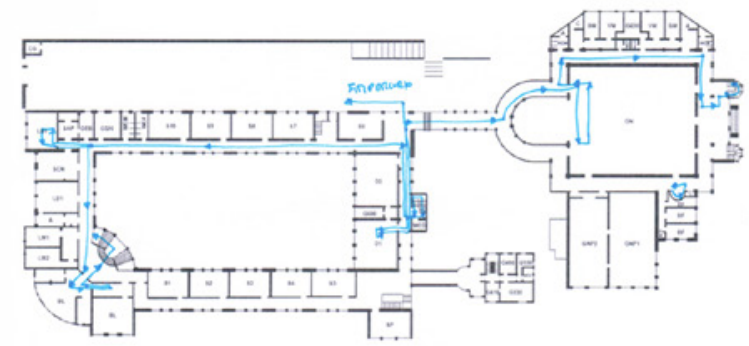

First floor

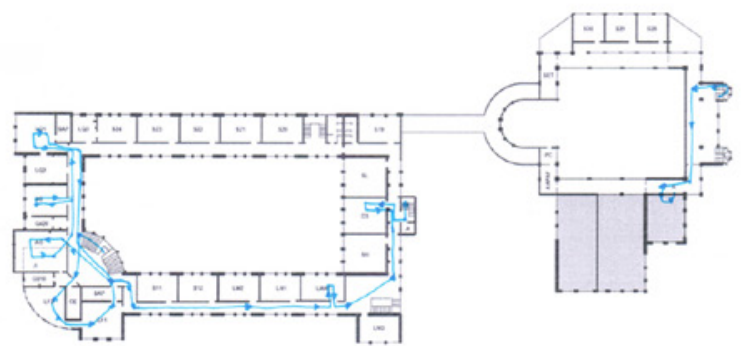

Second floor
Fig. 10 identifies the spaces considered by the students as spaces to stand informally on breaks of either long or short duration. These are clearly enlarged from the previous Fig. 9 related to the spaces afforded to them by the school faculty and staff. This leads to the conclusion that effective appropriation broadens the original expected usage of space and that there is a sense of belonging of the school by the students, which expands the overall adaptability of spaces from an originally more specific functionality as supportive spaces, to effectively productive spaces for learning.

Recalling Lynch (1977) on Studies of the spatial environment of adolescence, the sense of belonging by students can be associated with spatial appropriation, maintenance and fruition:

"The children should be living in places that have a clear social and spatial identity, places they can understand and take pride in. They should have a role to play in community maintenance and community celebration - particular functions to perform, particular places for which they are at least in part responsible." (Lynch, 1977, p. 57)

Ultimately, this confirms the hypothesis that informal spaces, such as atriums, and moving areas, such as circulations, are places where peer interaction frequently occurs, laying the foundations for knowledge acquisition and recognising them as active learning environments, not bounded by walls nor institutional practices.
Fig. 8 Description of events and experience in the school: Walkthrough (Images credits: School plans from the current building from José Falcão website: http://esjf.edu. pt, edited by the author) 

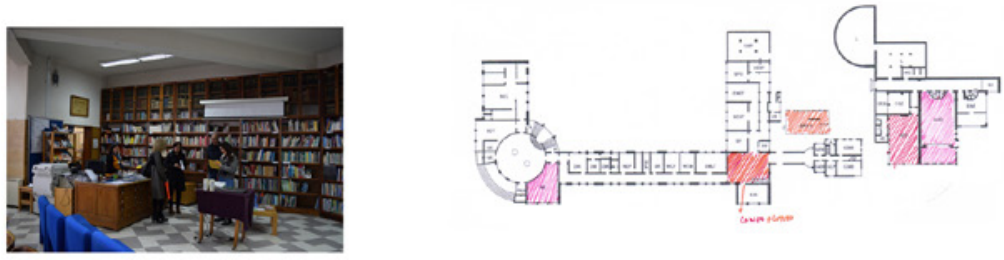

* Informal activities of long duration

4 Informal activities of short duration

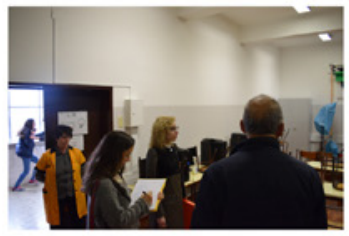

Ground floor

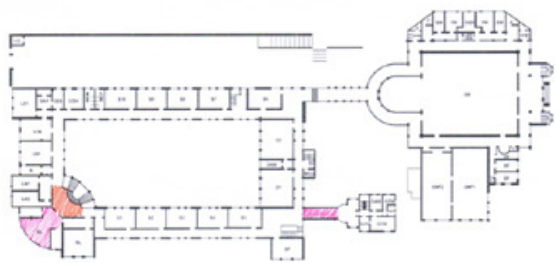

First floor
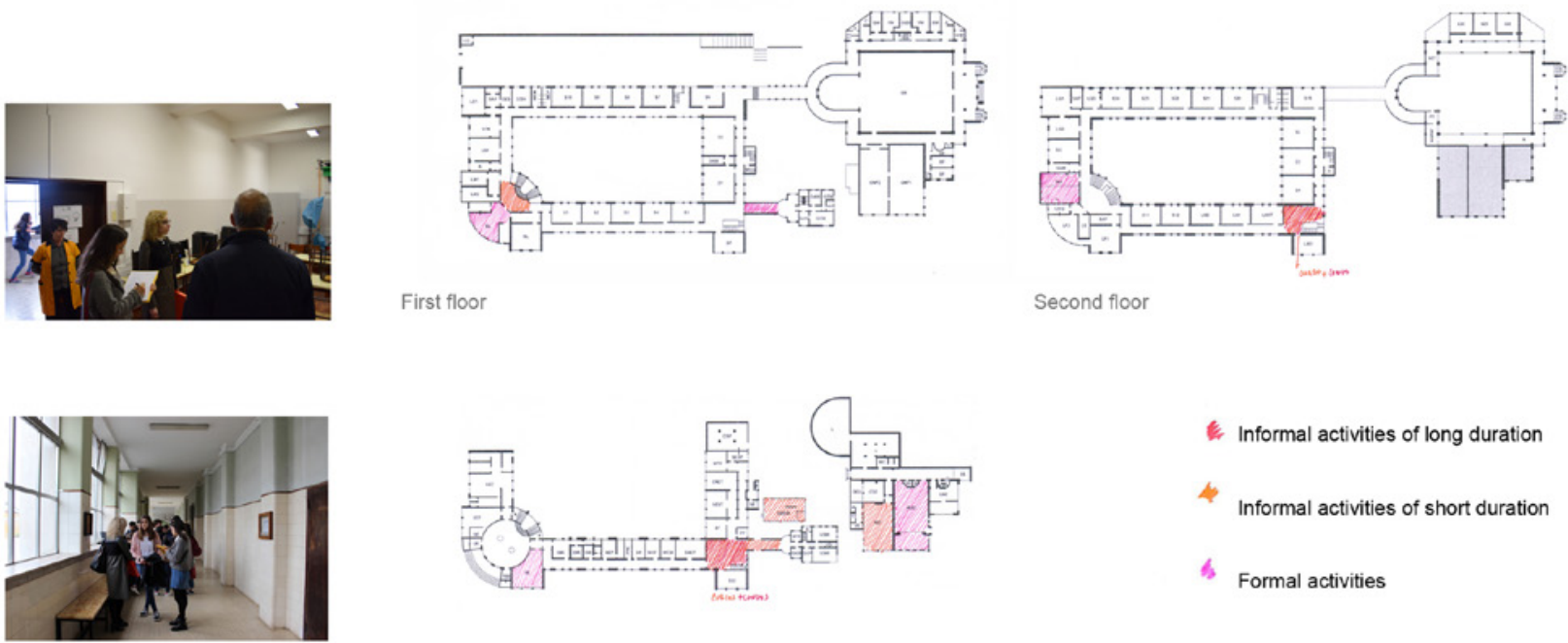

E Informal activities of long duration

Informal activities of short duration

6. Formal activities

Ground floor

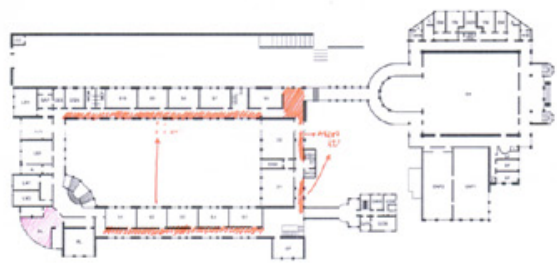

First floor

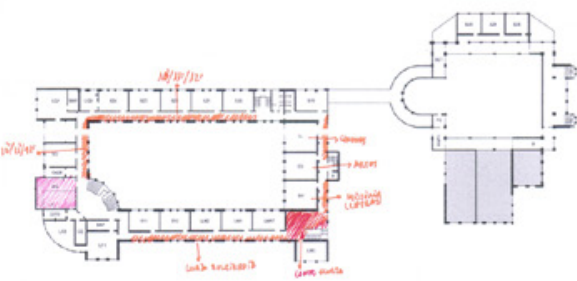

Second floor

C.
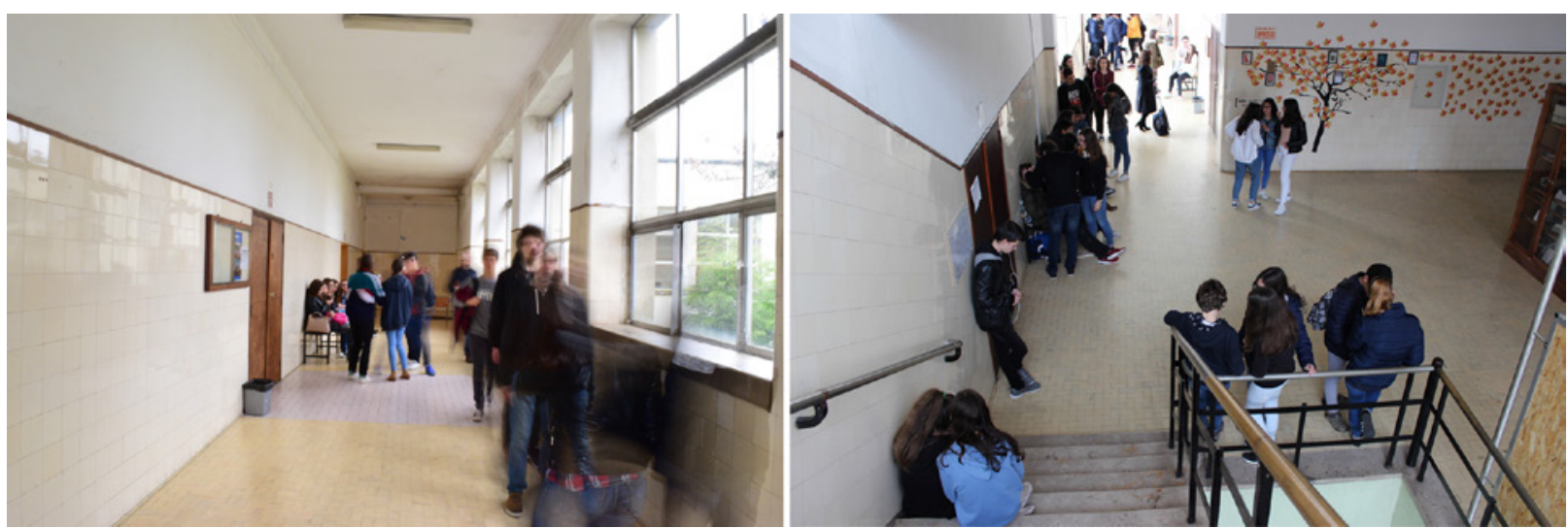


\section{Adaptability retrieval}

Having understood this school space, activities and effective spatial fruition, a discussion can be undertaken to identify the spaces where adaptability can be higher when triangulated between the previous milestones in a systematic overview.

From the analysis on spatial morphology, it could be concluded that the school has the potential to hold "learning streets", due to its corridors' width, environmental conditions, high integration, connectivity and visibility to the several surrounding spaces.

Nevertheless, the learning activities are mostly acknowledged on secluded spaces and not on the circulations or on mixed-use spaces. So, the potential of those circulations could be more acknowledged as both moving and standing spaces, where peer interaction and knowledge communication may occur (Fig. 11).

As prior seen, the gym is a highly integrated space, acting as a gathering space for its respective hallway on the school. Similarly, by analysing the school's morphology, it is noticeable that the interior courtyard is a central space for the main building, with high visual permeability. However, it is not currently used by the students on their daily routines. Still, it could provide the community with social and pedagogical experiences, visually perceived by its several surrounding corridors and classrooms and, hence, it could be socially and spatially engaging. Thus, the central courtyard could be acknowledged as an effective learning core of the school, gathering both formal and/ or informal activities and programmed and/or spontaneous events. This could also be projected onto other exterior spaces, such as the cafeteria grounds or the students' entrance. The latter has been recognised as a space where the students enjoy staying, and so, it could be afforded with a design, maintenance and use consistent with an active learning environment.

Likewise, morphologically deep spaces, with low integration on the school and with low connectivity, imply few accesses towards them and are also less used by the students. Therefore, commonly used spaces (such as the cafeteria or the canteen) could be placed in more integrated and connected areas and be more accessible and comfortable to reach.

The analysis on activity-space allocation also provided conclusions on the low activity mix. Besides the library, other spaces could consider widening their activities, enabling higher learning diversity.

Moreover, more spaces for informal learning and social activities could be provided to the students, besides the niches on the circulations. Both the morpho-syntactic analysis and the students' testimonies and walkthroughs have proven that the students' entrance is a significant space for the overall spatial system, which gathers the two buildings and which holds very high visual and axial integration. As it is a space that enables a wider pattern of encounters and co-presence that holds high visibility within the school and that is effectively used
Fig. 9 Description of events and experience in the school: Teachers' and staff's testimonies (Images credits: School plans from the current building from José Falcão website: http://esjf.edu. pt, edited by the author. Photos credits: author's archive)

Fig. 10 Description of events and experience in the school: Students' testimonies (Images credits: School plans from the current building from José Falcão website: http://esjf.edu. pt, edited by the author. Photos credits: author's archive)

Fig. 11 School's circulations used for moving and standing (Images credits: author's archive) 
with a corresponding significance by the students, its spatial and pedagogical centrality should be acknowledged. This would also imply future proofing these most preferred spaces by the students with furniture and physical comfort, from which the students' main hall is currently deprived.

\section{Discussion:}

\section{Possible widening of modernist adaptability?}

All in all, and despite its very assumed modernist matrix that constrains the adaptability of each space to a very specific functionality, this building has many assets, namely: facilities such as an amphitheatre, an auditorium with over 300 seats and a gym with a separate access used by an external community (Fig. 12); the previously referred wide, highly integrated and well-lit circulations; the wide provision of the laboratories and the library; the spatial quality of the building and its urban condition and location within the city.

A modernist spatial typology also needs to consider the spaces' syntactic connectivity and integration in regard to the pedagogical activities they accommodate, so that the learning processes can be more wide-ranging, encapsulating both formal and informal contexts, and also traditional face-to-face encounters, as well as the use of digital technologies and the respective viability of the non-face-toface learning paradigm. Thus, for more insightful and thorough spatial recommendations on providing for high quality and adaptable spaces, the school should be perceived as a whole, and rearrangements should be thought as a conjoint design for a whole learning space, more than a piecemeal rearrangement of separate spaces according to the most pressing technological, pedagogical and physical demands.

Specifically, interior and exterior spaces when considered as a whole provide a more diverse learning ambiance. Circulations and standing spaces, when morphologically connected, gather more students together. Likewise, formal and informal spaces, when considered adjacently, enhance a wider array of interrelated learning activities and experiences (Fig. 13).

In 1969 Giancarlo De Carlo (1969) ${ }^{3}$ writes to the Harvard Educational Review, the article 'Why/How to Build School Buildings', raising paramount questions on school spaces and proving a critical thinking on their answers. One of the questions proposed for discussion concerns the possible association of the learning activities to the buildings' quality:

"Is there a direct and reciprocal relationship between educational activity and the quality of the buildings in which it goes on?"

(De Carlo, 1969, p. 96)

This holds particular relevance because De Carlo argues for the evolving nature of the buildings according to its environmental 

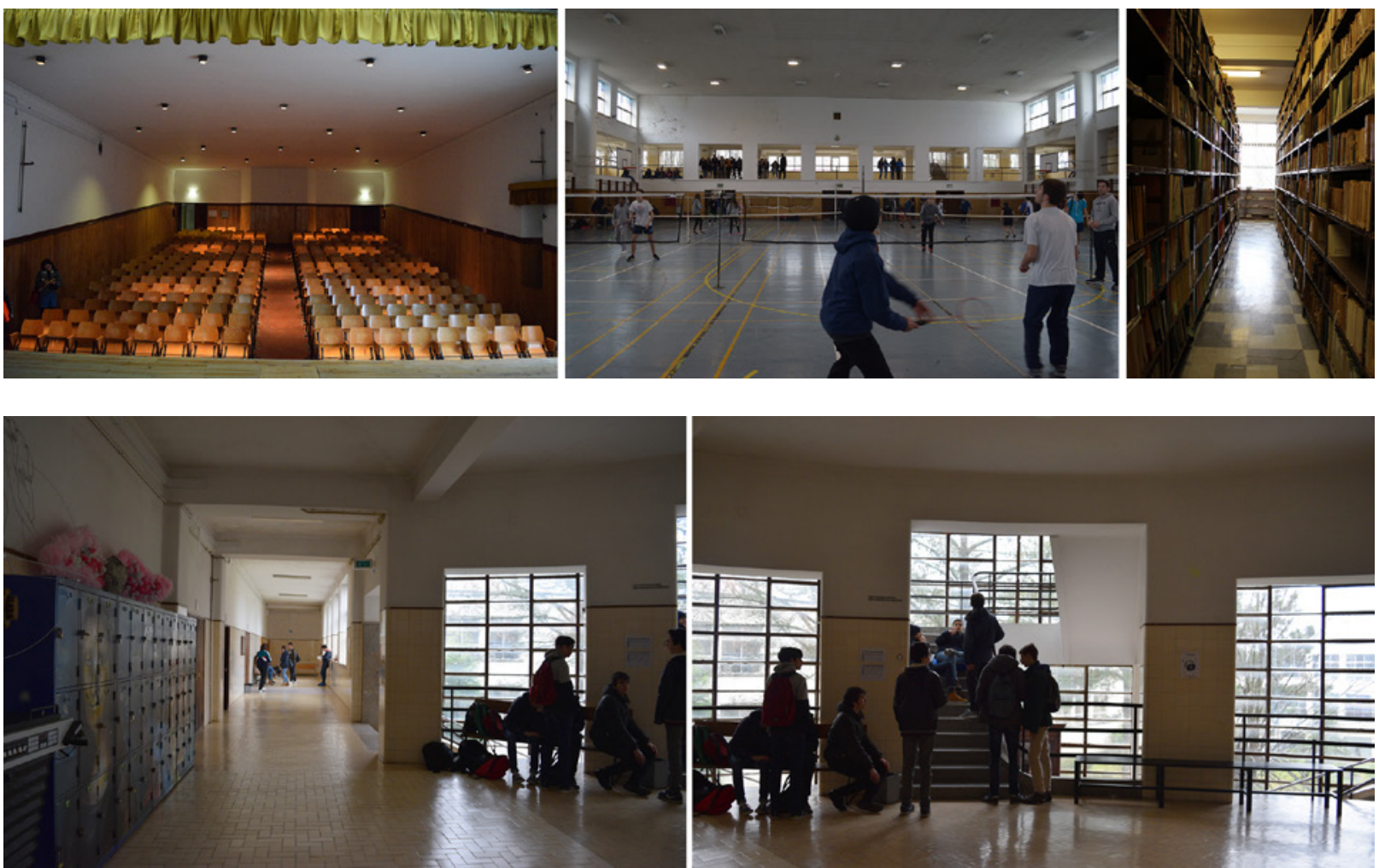

surroundings, which disregards fixed settled forms and suggests the need for "unstable configuration continually re-created" for the still unforeseen future (p. 102). De Carlo goes against the strong institutional space, its fixedness in aesthetic intentions rather than its engagement with time and use (p. 103). The higher entropy within space would mean the accommodation of a broader and fuller experience and not limited to a sole "connotation" or "event" (p. 103).

On his final remarks De Carlo considers that the design of schools can no longer be bounded and strict, enabling an "intense education" by "multiple active experiences". Thus, the design is no longer finished by the architect, but "continually readjusted by those who appropriate it (the students, the teachers, the people who use it for other things as well" (p. 107). This is central for assuming the school as a lived space that comprises various activities facilitated by space and not bounded by it.

The considerations taken on by De Carlo, are embedded in the questioning of the school and its spatial environment. Change is acknowledged and discussed on the activities the school space may accommodate, but also on their possible unforeseeable variances:

"The job of the architect who designs a school is to outline the organizational structure which should realize educational activities in space, whatever the complexity and the degree of contamination
Fig. 12 School spaces: auditorium, gym and library archives

(Images credits: author's archive)

Fig. 13 Socialisation and communication in the school's informal spaces

(Images credits: author's archive) 
with other activities which they may take on with time. The organizational structure will contain within itself the seeds of the formal configuration to which it will give rise or the basic ingredients of which it will be composed, or completely defined fragments around which its future development will evolve according to the circumstances, the intentions, and the reactivity of the situation in which one is working. The most important thing is that structure and form leave the greatest possible space for future evolution, because the real and most important designer of the school should be the collectivity which uses it." (De Carlo, 1969, p. 107)

From De Carlo's assertions, first we focus on the need to provide for change by means of the space's "structure and form", which in the present case study has been recognised as both an asset of architectural and urban quality, despite its originally defined functionality and specificity that might have hampered its spatial progression onwards to broader pedagogical and social uses. Secondly, De Carlo highlights the role of the collectivity in regard to their appropriation and effective fruition. This might make way for the pace of change and for spatial alterations within the school's adaptive reuse process, according to the current contextual constraints and pedagogical practices.

Overall, it can be argued that this school's modernist grounds endows the space with environmental and constructive quality that needs to be rethought and retrofitted from a functionalist spatial profile to a mixed-used and adaptable overall learning environment. This will cater for both the present pedagogical situation, as for the still unforeseeable changes on the forthcoming academic curricula, school community and urban requirements, the school will need to cope with in the future.

Finally, this paper has intended to discuss the adaptive reuse potential of a modernist Portuguese school and, for such purpose, it has undertaken a hybrid methodology composed of several milestones and distinct qualitative and quantitative approaches, which are ultimately combined into a hybrid methodology that articulates outcomes from each approach towards space use assessment.

This methodological approach aimed at identifying and assessing the adaptability condition of the school building and has already been applied to other case studies with different typological matrices ${ }^{4}$. For this case study, the application of the methodology focused on concluding whether a modernist typological spatial structure can accommodate current pedagogical practices.

Hence, the structure of this paper has progressed throughout the application of each of the three milestones proposed by the methodology, in which each complements the previous and whose piecemeal outcomes are largely correlated at the last stage, entitled "adaptability retrieval". 
Specifically, the description of the spatial sample analyses the spatial structure on which the teaching/learning process occurs, by means of a space syntax approach.

Subsequently, a description of activity-space allocations is undertaken to conclude whether the overall space's physical provision enables the activity allocation of the wide learning contexts considered nowadays. This is pursued by an analytical approach to space and use, by means of a feasibility matrix that pairs the school spaces with the activities they current hold. This leads to conclusions on the current allocation of the learning activities on the school, but could be developed even further, by proposing a feasibility matrix that maximises the "number of biunivocal corresponding matches between the sets of activities \{ai\} and spaces $\{$ ej\}"5 (Krüger, 1981, p. 1171), thus, taking full advantage of the allocational potential of the school's spaces.

A third milestone of this methodology consists on the description of events and experience, which comprises a qualitative approach to space use, by resorting to walkthroughs, observations of actual spatial occupancy, and the recollection of testimonies of the school community, for concluding on the effective spatial usage of the sample, analysed per se on stage one.

Finally, the adaptability retrieval triangulates information conveyed from both quantitative and qualitative outcomes, in order to provide a more thorough conclusion on: firstly, the adaptability potential of the school; secondly, whether there is an overall correlation between the spatial structure's potential and its effective occupancy; and thirdly, what can be proposed to enable a wider spatial adaptability towards contemporary learning practices.

Ultimately, the outputs presented can be both insightful as a theoretical research applied to a modernist case study, and can also inform the practice on this building's potential future rehabilitation according to the current pedagogical outlook. Furthermore, the methodology here presented is also acknowledged as a more general theoretical development, as well as an operative means of space use analysis that can be applied to other case studies of diverse typological structure in order to provide an analogous analysis on their adaptive reuse potential, or for future comparison between spatial school typologies on this behalf.

\section{Acknowledgments}

We kindly acknowledge all the community of José Falcão School: direction, teachers, staff and students, who have provided us with all the materials and a deep insight on both the school physical structure and the living and learning experience within. The photos from the author's archive have been taken with the support of Francisca Biscaia and Ana Bagulho, to whom we kindly thank. 
$1 \rightarrow$ "[...] schools are both physical spaces and communities of educational and social practices. The relationship of these two aspects of school are vital for its success and are foundational for developing interdisciplinary understandings of school design." (Woolner, 2015, p. 10).

$2 \rightarrow$ See also "participant-led tour of the school" (Duarte, Veloso, Marques and Sebastião, 2014, p. 15).

$3 \rightarrow$ Originally published in the Harvard Educational Review, Vol. 39, No. 4, 1969 and consulted in the reprint edition included in: Coates, G. (Ed.) (1974). Alternative learning environments. (pp. 96-108). Stroudsburg, Pa: Dowden, Hutchinson \& Ross.

$4 \rightarrow$ For further reading on this methodology see: Coelho, C. (2017). Life within architecture from design process to space use. Adaptability in school buildings today - A methodological approach. PhD Thesis in Architecture. Departamento de Arquitetura da Faculdade de Ciências e Tecnologia. Universidade de Coimbra.

$5 \rightarrow$ Free translation of the original quote in Portuguese. 
Benedikt, M. (1979). To take hold of space: isovists and isovist fields. Environment and Planning $B$, volume 6, 47-65.

-

Brand, S. (1994). How buildings learn: What Happens After They're Built. New York: Viking Adult.

-

Coelho, C. (2017). Life within architecture from design process to space use. Adaptability in school buildings today - A methodological approach. PhD Thesis in Architecture. Departamento de Arquitetura da Faculdade de Ciências e Tecnologia. Universidade de Coimbra.

De Carlo, G. (1969). Why/How to Build School Buildings. In G. Coates (Ed.) (1974). Alternative learning environments. (pp. 96-108). Stroudsburg, Pa: Dowden, Hutchinson \& Ross.

Docomomo (2015). Docomomo Journal. Reuse, Renovation and Restoration, 52, 2015/01. A. Tostões; Z. Ferreira (Eds.). International working-party for documentation and conservation of buildings, sites and neighbourhoods of the Modern Movement.

Docomomo (2016). 14 ${ }^{\text {th }}$ international conference proceedings. 'Adaptive reuse: The modern movement towards the future'. 6-9 september, 2016. A. Tostões; Z. Ferreira (Eds.). Lisbon: Docomomo International.

-

Docomomo Ibérico (2015). La arquitectura del Movimiento Moderno y la educación. Actas del VIII Congreso. Docomomo Ibérico, Málaga, 27, 28 y 29 de Noviembre de 2013.

Duarte, A.; Veloso, L.; Marques, J.; Sebastião. J. (2014). Site-specific focus groups: analysing learning spaces in situ. International Journal of Social Research Methodology.

Fawcett, W. (1978). A Mathematical Approach to Adaptability in Buildings. Doctoral Thesis. S.I.: University of Cambridge.
Heitor, T. (2001). A vulnerabilidade do espaço em Chelas. Uma abordagem sintáctica. Fundação Calouste Gulbenkian, Fundação para a Ciência e a Tecnologia. Porto: Imprensa Portuguesa.

Heitor, T. (2005). Potential Problems and Challenges in Defining International Design Principles for Schools. In Papers from OECD/PEB 'Expert's group Meetings on Evaluating Quality in Educational Facilities'. (pp. 44-54). Lisbon.

Hertzberger, H. (2008). Space and Learning: Lessons in Architecture 3. Rotterdam: 010 Publishers.

-

Hillier, B.; Hanson, J. (1984). The Social Logic of Space. Cambridge: Cambridge University Press.

Hillier, B., Hanson, J., Peponis, J., Hudson, J. and Burdett, R. (1983). Space Syntax: A Different Urban Perspective. The Architects'Journal 30, Volume: 178, 48, Nov 1983, 47-54, 59-63.

Kincaid, D. (2003). Adapting buildings for changing uses: Guidelines for change of use refurbishment. London: Spon Press.

Krüger, M. J. (1981). Maximização da adaptabilidade. In Ciência e Cultura, 33 (9), 11691182.

\section{-}

Krüger, M. J. (1992). Caracterização e Programação de Edifícios Complexos. Departamento de Engenharia Civil. Instituto Superior Técnico. Universidade Técnica de Lisboa. Abril de 1992 (Publicação Nº 78).

Llewelyn-Davies, R.; Weeks, J. (1952). The Hertfordshire Achievement. The Architectural Review, 111(666), 367-372.

Lynch, K. (Ed.) (1977). Growing up in cities: Studies of the spatial environment of adolescence in Cracow, Melbourne, Mexico City, Salta, Toluca, and Warszawa. Cambridge, Mass: MIT Press.
Monahan, T. (2002). Flexible Space \& Built Pedagogy: Emerging IT Embodiments. Inventio 4 (1): 1-19.

\section{-}

Moniz, G. C. (2003). O Liceu Moderno. Do

Programa-tipo ao Liceu-máquina. In A. Tostões; M. Lacerda; M. Soromenho (Coords.). Arquitectura Moderna Portuguesa 1920-1970. (pp. 66-81). Lisboa: Instituto Português do Património Arquitectónico.

Moniz, G. C. (2007). Arquitectura e Instrução. O projecto moderno do liceu 1836-1936. Coimbra: e|d|arq.

Moniz, G. C. (2015). Espaços de aprendizagem: construção e transformação da escola moderna. In Docomomo Ibérico (2015). La arquitectura del Movimiento Moderno y la educación. Actas del VIII Congreso. Docomomo Ibérico, Málaga, 27, 28 y 29 de Noviembre de 2013. (pp. 123-136).

-

Organisation for Economic Co-Operation and Development. Programme on Educational Building (1976). Providing for Future Change: Adaptability and Flexibility in School Building. Paris: Organization for Economic Co-operation and Development.

Rodrigues, A. S. (2003). Liceu José Falcão, em Coimbra. In A. Nóvoa; A. Santa-Clara. Liceus de Portugal: Histórias, Arquivos, Memórias. (pp. 222 241). Lisboa: Asa.

Woolner, P. (Ed.) (2015). School design together. London: Routledge. 